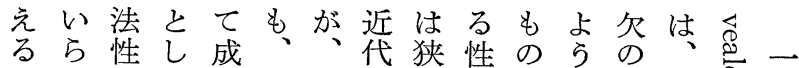
で机のて立そ仏当義格がな契そ气般 ある道考し:の教、にを立啓機れるに ろの理えて釈も口は有て示とら气二 ら专ならい尊まッ自すら宗しの器ダ

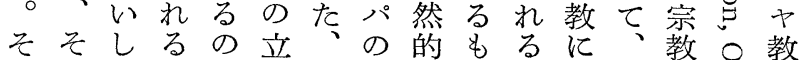
しのそ性で場釈㤵理の。対そ肪蚶や てよれ格あを尊蒙性とそして啓名回 まらにをるどに主の たな類有かとよ.義認般て、根と气 キ性すしらまつの識に仏自拠い宓な リ格るて、でて時に考教然をら怘い スを言いよ\&創代基えは的もも气 气 卜示葉るり超唱につう自宗つの怘キ 教しがか高方さ考くれ然教てを步 㤎て仏ら次出れえ宗て的乙いそと 、い教でのたたら教い宗壱るのよト とるにあ意永もれでる教志か成ば教 りかおる味遠のた市。と气ら立れは

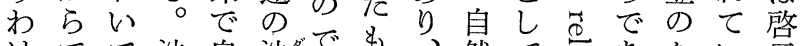

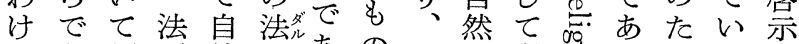

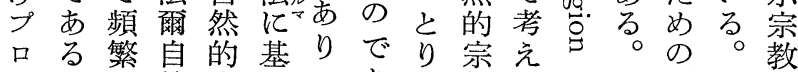

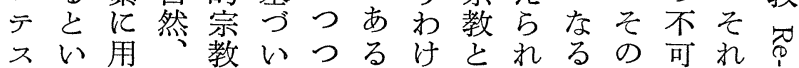

釈なな わ示涂しし教調さ夕

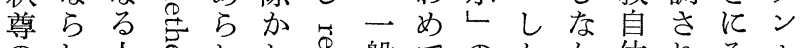
のし人总机梳般てのかか体れそ卜 正め間のるる神 賞ら的にここ苛整く題なたら支点学 のれな通とと。示見をがとちをでに 事る立ずを、を今とら考らいでり仏お 実と場る意意しいれえよう積、教け もと概味味とらるより点極仏をる まで理念方しは言現ら広も的教含よ たあ性なる、、葉象とくそに自めら つでの\&し何のなす人と考体てに 単てはでのたか意のる類に察の他綮 な、把あでが隠意で場の考し側宗示 るそ握る金あつさ市あ合宗えよに教の 人のさ的絶 間よれそつそたる。そ全れといら対 のらえれてのも般るすて区的 主ななはギもの总はののるも別な

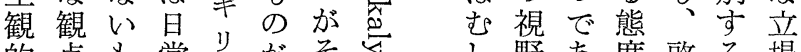
的点も常リ雀そ㞤野あ度啓る 場 なかの的シ市の总方にるが示之老 認らがなャら覆へ諸立。殆のい主

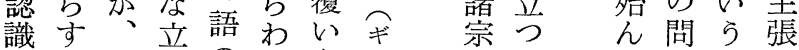
のれあ場の真省取な教て 題面し 章ばらか福理し取な 


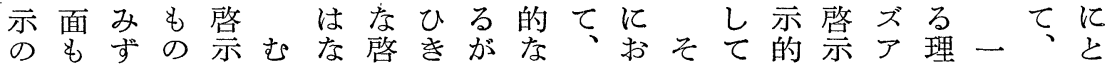
根考かで宗しか示も、啓そけしいな宗ッ神般㤵ぐ 仏拠えらは教ろろ内と整示のるてた内教プ論に示ま 教とらのなとキう容し示と綮むと容加さ的啓的る 㤵しれらく自りか劣てのは尔しい契られな示なも 綮てるち、然ス。有考概本な概ろら機区て立宗内の のののにか的トすえ创質意念宗点を別き場教実で 問神で不え宗教 のあ可つ教 的 るるを的味は教怔考さたととをは

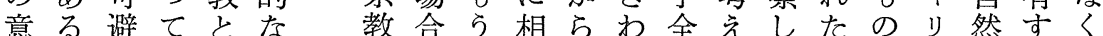
め志。的自は代

く度しに然必グ

るい加啓的市?

論しし示宗し 的

考人なの教もな 格 が 契 自 相 立

河 等 ら 機 体 互 場 の、をがにを 宗場もに亦学考察れもキ自有な 教合ら相らわ全えしたのり然す し仏度宁光てのれゆ然あ下宗も永 て教こるれ特立ねと的り教教の遠 考にこ面ば殊場ばら宗、のととの えおでをもをなか教か立の云法名 らい一認ち類ららすに場区えの? れて般めろ型見なるおるの別る釈 るも的ねんにるい視い対対自の尊 こまなば仏属との点て決決体でに とた原な教すきでが、自をははお がき初らはる、亦最そ体通、なけ でわ的なキもキる初れにし近かる きめないリのリ○かのよて代ら開 るて立のスでス らもつクにら示

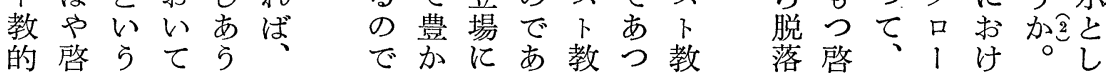

のさ永仏味い指仏でて啓 し展に遠しにて摘らあの示一教さ た開かのがお永がのる神ではにて がのか法釈い遠あ序。のあ歴お仏 つ原るの尊てのる言そ自り史け教 て点点開にで法よにの己、的るに 更とで示おあうらおこ啓イな啓お になそのいるすにいと示称示け

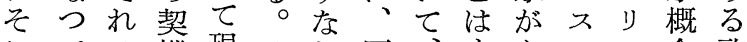
こては機現そわ歴、すなのス念啓 かい後と起しち史歴でさ存卜に示 らるになして法的史にれ在・対の 第の続つ出そ身なの姉てそ, イ応問 元でくて現の仏仏中崎いの壬し 題 にあ大いすを陀に正たも崎市てを

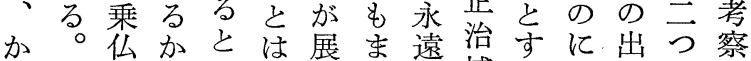

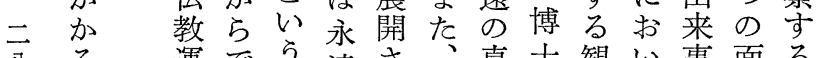
八る運でら遠さ真士観い事面る 五仏動も形祡れそ理の点て自怔場 陀にあでなての年可絶体考合 そおる釈法ゆ仏見現相対が党 そ け。釈法尔陀ら身応的唯ら一 れるる尊市之自れ仏卞在二れ応

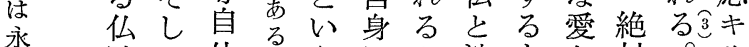
遠陀て体いらにと法\&と対。リ

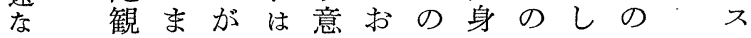

おいをから前 い視仏らな提 て野教解いは そがに放

の開おして必 問かい、のず 題れて一よし をて 積般らも 考ゆ極的に啓 えく的な㤵示 てとに立示そ みと考場概 の よに光に念文 らなるひをの とるときキに 思のとをりと らでにどスつ のはよしトて でなつ、教不 あかて 改な可 るろ仏め特欠 ら教て 殊 の 研啓的契 究 示 概 機 以のの念と 下新問規は にし題定な 
仏 真に教さらららでい意舟にののわ乗へてが仏る

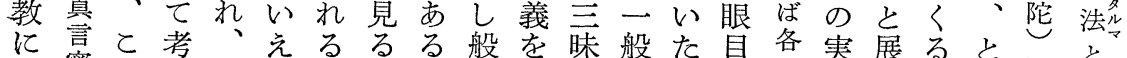

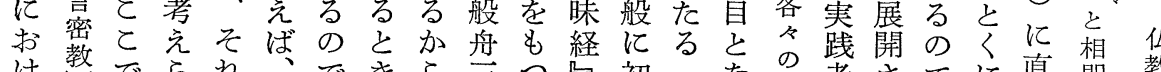
け教でられ、できら方つ初—なな者さでに直即教 実問 る

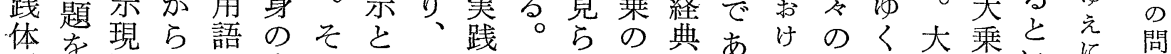
系通しでの揫れしかのそれ実類るる主の乗仏いに題

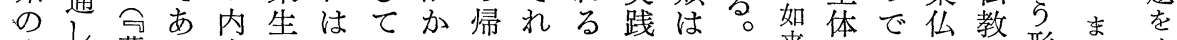

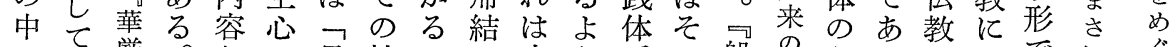

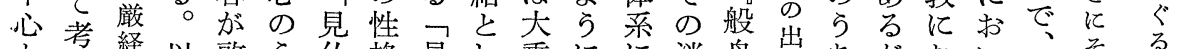

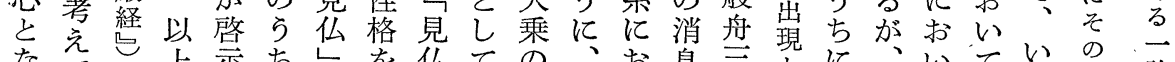

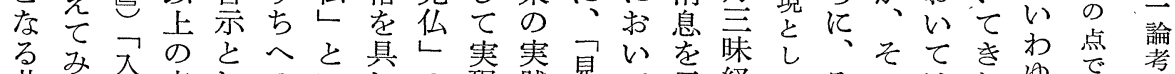

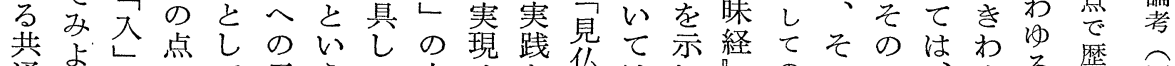

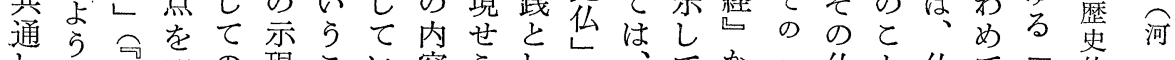

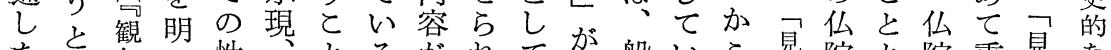
た思無ら性々るがれて热般いら見陀々陀重見な

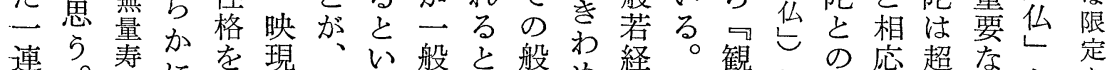

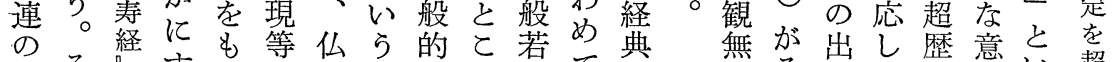

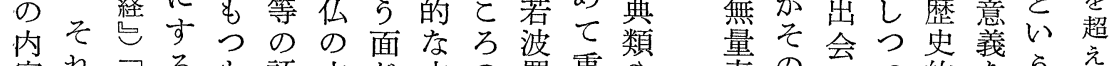

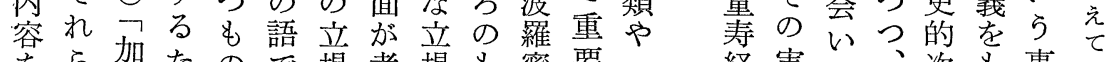
をら妿たの艺場考場も蜜要可経実へ、次も事い 集は持めと示汃加のな般等践い大元つ柄る

例現たこわえをそ宇この等市数市

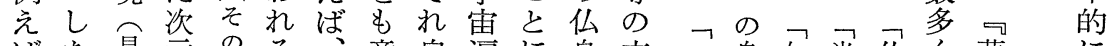
ばた見元のる、意自遍に身文二身如光仏く華荠

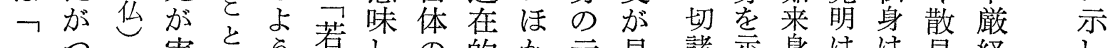

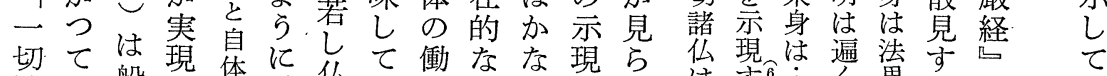

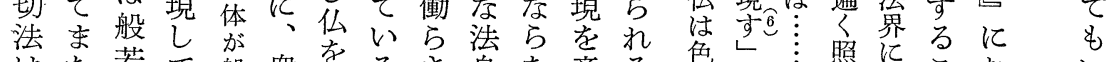

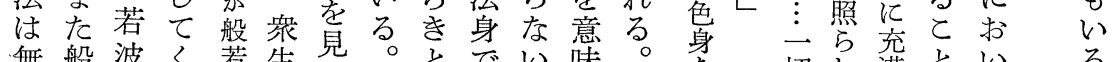

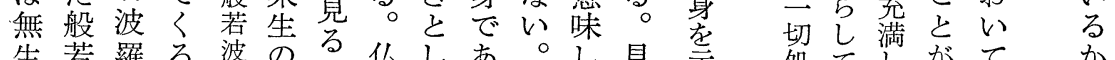

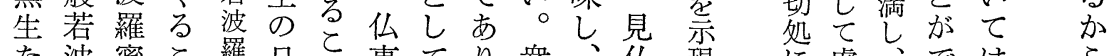

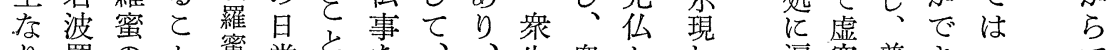

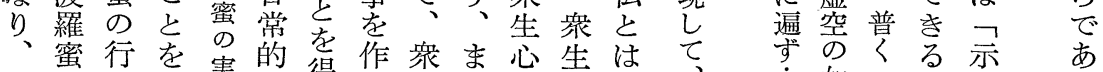

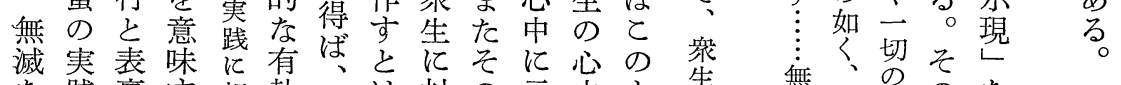

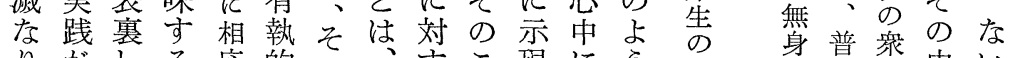

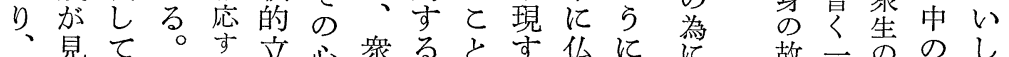

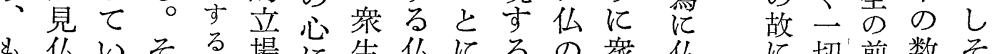
も仏いそる場に生仏にるの衆仏切前数そ しのるの仏加所の事お仏世生事、衆に例れ よ行のよ仏突著立がい身界の索衆生現をに くにでら身き者場作ては㤎主作生前妾挙類

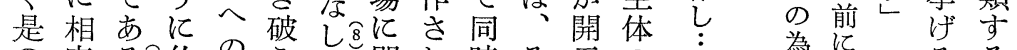

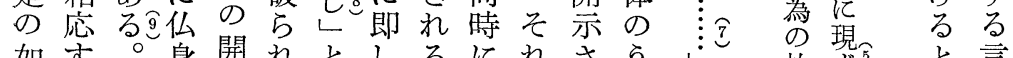

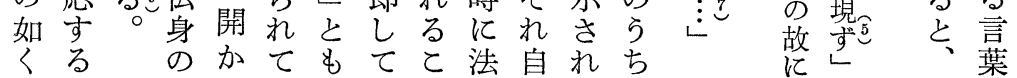

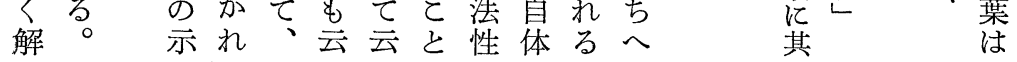


のとい㤵につれ平いへて性源る平的立生波す で不て示おてらへての、しの的如をなすの羅それ あ二実とけくの心衆仏三た成な来開衆る立蜜のば 仏る平はいるると教は生自うが立場のく生と場によ諸 教。等衆らよとと怔の体のつ卞と出とのいがおうら仏

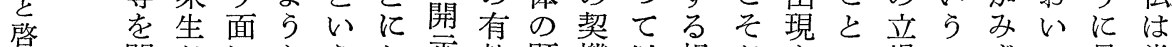
示開がにならお示執顕機以根がをで場とずて見常

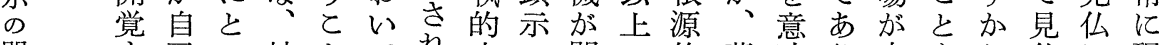
問委导心゙神とてれ立で開の的華味り突をら仏に現 題るみまので実る場あ悟如な綮し、き意のがお在 をとする人市はて がりさき場思てそ破味空成いすす木

め

ぐ

る いかも間る仏と突つれ点に想いしらし性就てし ららのへ。とできつ㤵かほのるてれてれ般等 、のでのそ秋あ破、等ら加のまていのし若の

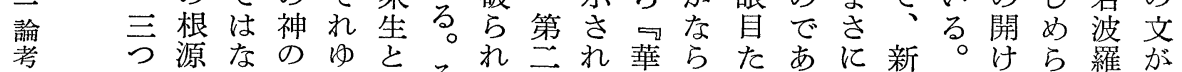

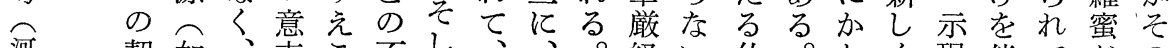
河契如、志と不し人経い仏。かく現伴てがの 機来同にと三て衆ま一经。とそる根とつゆ成内 婆を蔵時よで平第生さはの衆し根源はてくぜ実

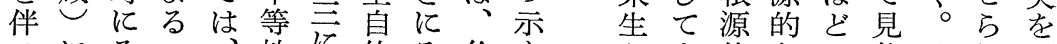
つにそ二性に体そ仏守它ま的なと仏それ示

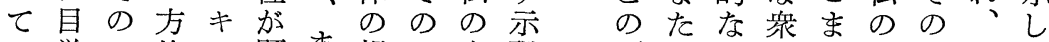
の覚こ的り顕ま根こ衆現不少場生で事こまて

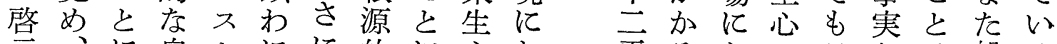
示、に自卜にに的に心お平る的の品は般る な仏お已教なそ地お中心等根け地常成衆若。

\section{諸二なる観くもも は両を属び立体こ構して}

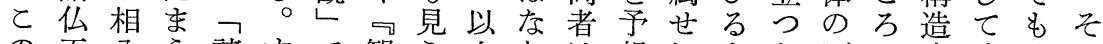
の正八ら諸すで観ら上か加想しよが面で自成そし

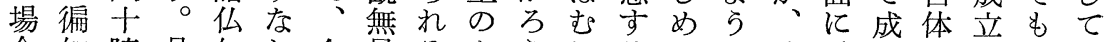
合知随是如わ念量るよらしるるに啓重立はすす仏更 も海形の来ち仏寿。らからと心质示点し㤵るとに 仏は好故は、严経浄な。相ときる。居を示も衆と 身心なに是昧见土内互に性。開おいにの生と の想り、汝れ の・に教容によ格し 衆よ、等法存おには循つのからといあの大 生り是心界在いおま環てもし面きいてる不切 心生のに身論ていた

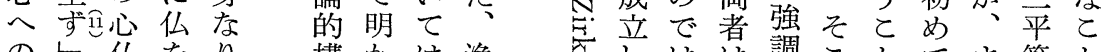
のட仏をり、構かは浄鸟しはは調ととてま等と

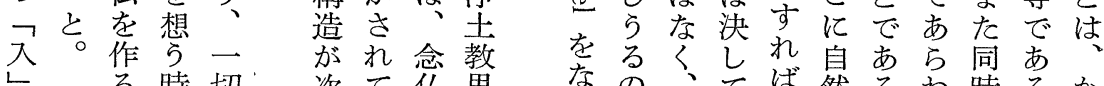

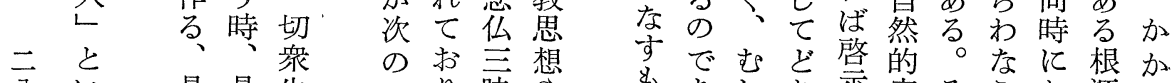
八

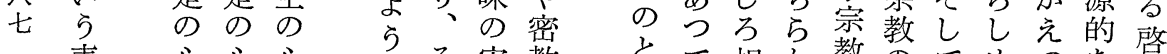

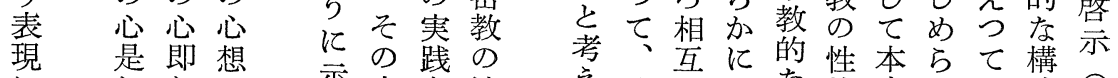

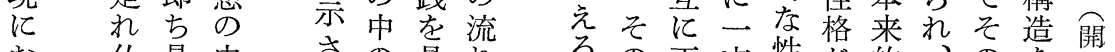

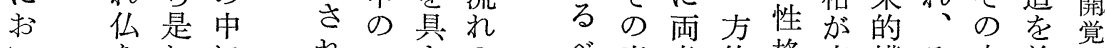

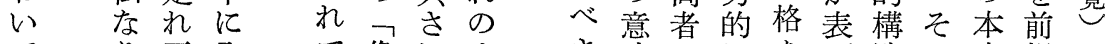

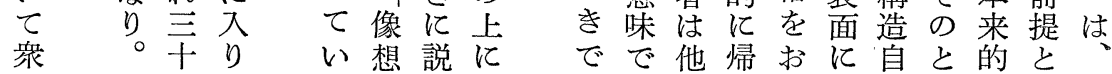




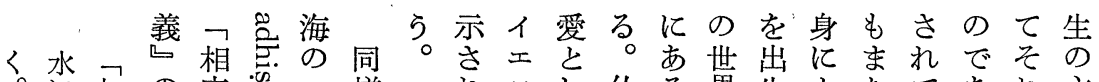

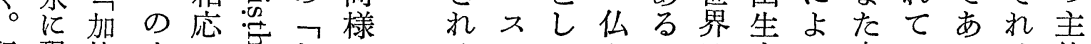

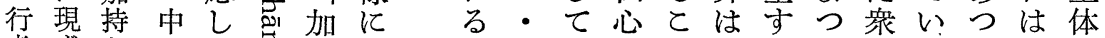
者ずとでか学持しとキのととてる生るて実へ

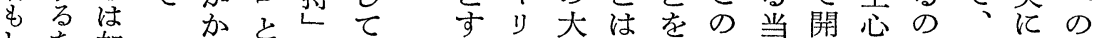
よ妿来桇はの㤵

$<と$ の

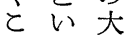

のい慈

り、概 示

るス慈大知よ体かをでか衆仏

キト悲慈るらとれ離あか生身 リにが悲。にもたれるる心の問 あも 念の 理、と综中容 趣行衆ととには を者生 と 明 観 の の 念心信 れ能々 ばく伀表

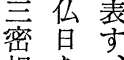
岨感仏 必感 位 るるの

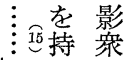
名生

之立瞭真 さうに言 れこ見密 るとる教 がしこに 空集とお 海処がで 即意る る 身味。わ 盛方加诗空
スおそ是そしな衆て。衆自開題 トいてれしてつ生はむ生身示を 教てでなて、ての存しののの、め の絶啓り翟さ華い根在ろ心根示ら 立対示しら簃る源しかが源現 る 場的さとにのの的えか仏的が論 となれ示存唯でななると次論考 相神るさ仏心市心い衆不元じ 応のの注身縁るがの生三のら河 す意でるを起。実で心二開机 る志あよ見と念にあ加示る 婆 もとるらる表仏無つらでとの のしてに者裏等限てすす市相で

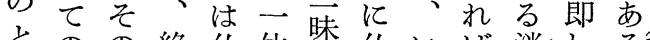

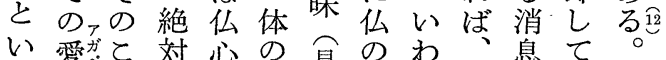
え荢と的を関見世㕕世仏息でいて よ啓はな見係心界仏身示るし
教な題らはのい加両 之かをれ覚際法乃契 以 はろむるの法ら機上

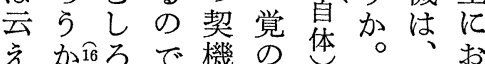
えか16ろで機の絜。、お なそ極るす機覚教して と为的。うは觉的乃示 さとにとてと憵な相さ えも論のはと示観互れ 考覚究よじまし点にた え しらめでのか予よ ら綮意なても関ら想ら

れ示義観本法係市しに るのづ点来をにれあ

か㓞けかのよ相ばつ自 ら契てら法り応、て然 で機ゆ仏之処すそい的 あ通く教しとるれる宗 る通必にてしもはと教 な要おあつの法云と な乩りつで爾え啓 いあるわ㐫あのる示 仏る㤵な、る道の宗 以教の示らそが理で教 上はでのしの、坮は 仏は問め法そななの
来啓吕て、交てて、に同と な示構そ方の両いい内い 構の造れる場者てて容て 造契を息い決は仏持をい は笑機前体う本日の示る あ機提はのて来は当し

ら都と無で加不み体てか わ通し自はと立ずたか れ守て性な持平かるるる よと加ない之等ら衆。加 ら市持る車らでの生加持 がな活耐らあ生心との なく可と者うつ起が持構 いし能し縁のてのあは造 のてとて起実互根ら相は では店的体具源わ依可

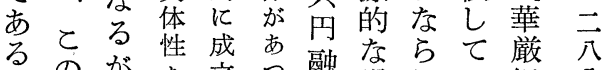
るこのが性成立融な場しい経公

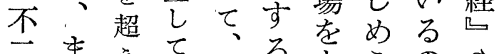

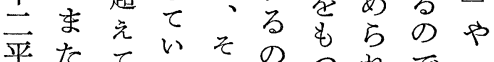
等て なのるで実あでまり経 る加 こあ体るあた た、兄 本持かつが。つ持加と 
$1211 \quad 10$

$\begin{array}{llllll}9 & 8 & 7 & 6 & 5 & 4\end{array}$

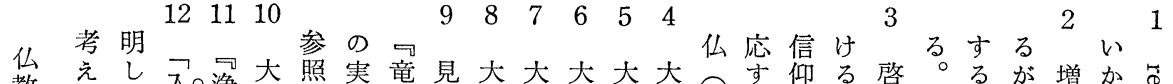

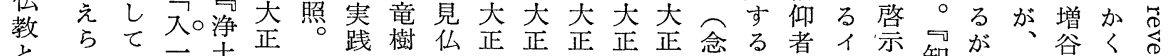

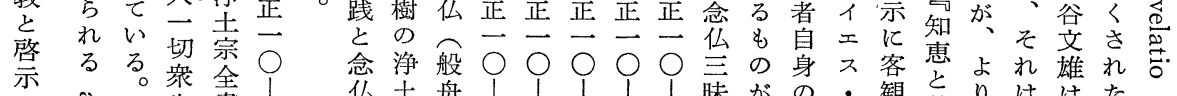

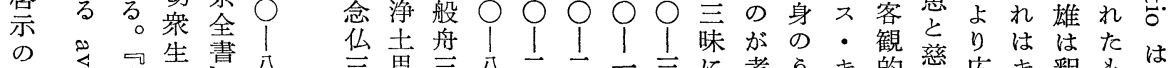

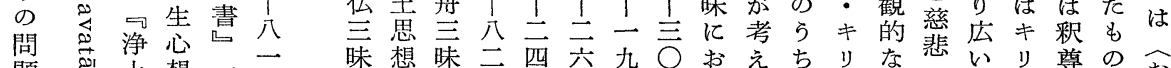

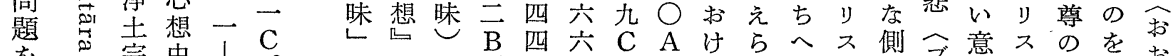

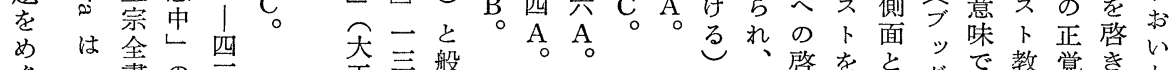

る 入畫の文。

二る四を学真䍜

論とり善と導研服維

考と三導究部の

河と

ᄀ $\overrightarrow{\mathrm{A}}$ 映。第淳 係

婆姿。現。四竜己

を入筛分輯樹い

万㤁輯にて

わ相想它声は

す当中列長

とすと分萻岡

とると説頁薩也

宗者とし観に種な意总とす

体歴あの側角啓意味志と

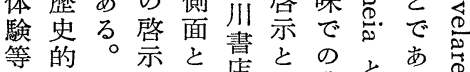
が仏仏示客と整比る

そ陀教客考九て示此。を

れがに観え公考概較き前

に、お面ら頁え念乍古提

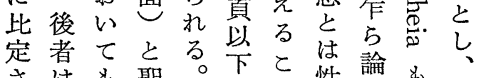

さ例そ霊歴参と性究同そ

るえれに史照がをし義の

○ばによにで異て市

見相るお仙いお

$\begin{array}{llll}16 & 15 & 14 & 13\end{array}$

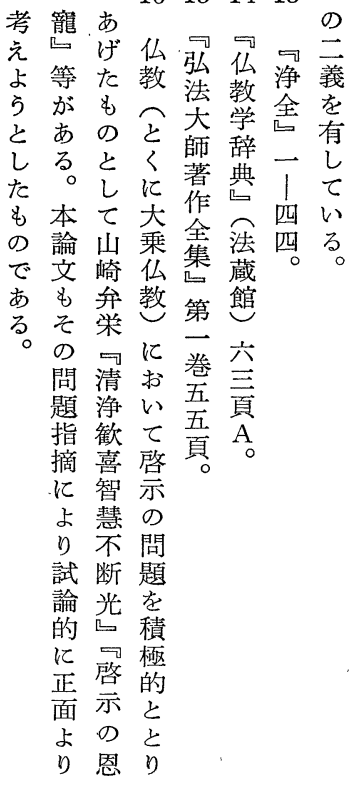

